\title{
УДК 642.5
}

\section{РЕТРОСПЕКТИВНИЙ АНАЛІЗ РОЗВИТКУ ЗАКЛАДІВ РЕСТОРАННОГО ГОСПОДАРСТВА}

\author{
О. Гаталяк, Н. Ганич \\ Львівський національний університет імені Івана Франка \\ вул. Університетська, 1, м. Львів 79000 Україна
}

\begin{abstract}
Висвітлено розвиток закладів ресторанного господарства у ретроспетиві, проаналізовано історичні періоди розвитку сфери ресторанного господарства.

Ключові слова: ресторанне господарство, таверни, караван-сараї, кав’ярні, ресторани.
\end{abstract}

Всебічне дослідження сфери ресторанного бізнесу передбачає аналіз не тільки його економічних та соціальних аспектів, а й початкових форм ресторанного господарства, закладів ресторанного господарства різних типів та цінових категорій, що діяли в різні часи.

Метою статті є ретроспективний аналіз розвитку закладів ресторанного господарства, висвітлення його стану і розвитку на підставі літературних джерел у різні історичні періоди, вмявлення тенденцій, їх розвитку.

Вітчизняні та зарубіжні науковці досліджують різні сторони розвитку ресторанного господарства. Сучасні форми організації роботи закладів ресторанного господарства знайшли відображення у працях В.В. Архіпова, Н.О. П'ятницької. Дослідженню менеджменту ресторанного господарства присвячені публікації M. І. Кабушкіна, Л.І. Нечаюка. Історію розвитку закладів ресторанного господарства та індустрії гостинності загалом вивчали Г.А.Папирян, Дж.Р.Уокер.

Заклади харчування - праобрази сучасних ресторанів, - відомі віддавна. Згадки про подібні підприємства - таверни - містять стародавні манускрипти, зокрема Кодекс царя Вавилонії Хамурапі, написаний близько 1700 р. до н. е.

У Стародавній Греції вже в I тис. до н. е. таверни були невід’ємною складовою суспільного життя. Насамперед вони були призначені для надання послуг харчування. Дещо пізніше, з розвитком торгівлі, з'явився такий тип підприємств, як постоялі двори. Найбільш розгалужена мережа постоялих дворів була створена на території Римської імперії. Постоялі двори розташовувались уздовж головних доріг, у містах і селах, на відстані 25 миль (40,225 км) один від одного. Послуги у таких закладах надавались за класовою ознакою: ні купці, ані інші відвідувачі - представники простих станів - не могли харчуватися разом $з$ державними службовцями чи урядовими гінцями. Ця обставина вплинула на якість та асортимент послуг: і таверни, і постоялі двори, призначені для обслуговування населення нижчих станів, надавали мінімальні послуги харчування та розміщення.

Розвитку закладів харчування сприяло пожвавлення торговельних зв'язків 3 країнами Близького Сходу та Азії, зокрема, в тих регіонах, територією яких пролягали важливі торговельні шляхи і пересувались каравани. На відпочинок каравани зупи-

(C) Гаталяк О., Ганич Н., 2013 
нялись у караван-сараях, відомих з II-I тис. до н. е. Особливого поширення вони набули в середньовіччя, у IX-XV ст. Відстань між караван-сараями зазвичай становила 30-40 км, що відповідало денному переходу каравана.

У середньовічній Османській імперії, від Кавказу на півночі до Середземномор'я на півдні, діяла розгалужена мережа караван-сараїв. Найзахідніші караван-сараї були розташовані поблизу сучасної Шкодри в Албанії і навіть біля озера Врана (сучасна Хорватія), а найсхідніші - в Афганістані.

У караван-сараях можна було не лише попоїсти чи переночувати. Тут були лазні, пункти обміну грошових знаків і торгівлі тощо.

Після падіння Римської імперії 476 р. в розвитку підприємств харчування розпочався новий період.

Вагомим чинником розвитку підприємств середньовіччя були релігійні традиції. В цей час помітно збільшується кількість паломників, ночівлю та харчування для яких організовували монастирі. Подібні функції здійснювали й інші заклади. Так, за наказом імператора Карла Великого (742-814) були створені спеціальні будинки для відпочинку паломників. Тут можна було скористатися послугами цирюльника, шевця, отримати безкоштовно хліб, фрукти, горіхи тощо.

Безкоштовні послуги монастирів гальмували розвиток приватних підприємств. В Англії поштовхом до розвитку постоялих дворів і таверн стала секуляризація монастирів у період пізнього Середньовіччя. Мандрівники вже не могли розраховувати на безкоштовні послуги розміщення та харчування і вимушені були звертатися до приватних постоялих дворів.

У XII - XIII ст. постоялі, або гостинні, двори з'являються на території Київської Русі. Вони були призначені для всіх категорій населення і початково мали вигляд прямокутного майдану, обнесеного кам'яними чи дерев'яними приміщеннями, об'єднаними критими галереями. Тут можна було розмістити коней і транспортні засоби відвідувачів, тобто пропонувалися послуги “постою”. У містах та інших поселеннях віддавна відкривалися корчми, куди приходили не тільки поїсти і випити чогось міцного, там засідали земські суди, оголошувалися людям найважливіші новини. В деяких регіонах корчми називали шинками, що фактично були аналогами сучасних ресторанів. У плануванні корчма найчастіше складалась 3 двох чітко розділених частин: приміщень для харчування і для ночівлі. Для харчування призначались дві кімнати: в одній був шинок з прилавками, в іншій - один або декілька масивних столів, тут відвідувачі могли відпочивати і розважатись. Роботу корчмарів шляхетні міщани вважали непристойною, тому їі традиційно виконували люди неукраїнського походження - євреї, вірмени, греки тощо. Корчмарі мали чималі доходи і сплачували податки. Майже в кожному місті була, щонайменше, одна корчма, а десь - i по дві, i по чотири. Спочатку корчми були вільними установами і лише з часом стали князівськими, казенними, тоді стали з'являтися і таємні.

Ще одним закладом харчування, в якому подавали насамперед алкогольні напої, були кнайпи. Цей аналог кафе або невеликого ресторану набув особливого поширення у Галичині, зокрема, у Львові.

На території Московського царства Iван IV заборонив продавати горілку, а пити iï дозволив тільки опричникам і для цього наказав побудувати особливий будинок, 
який назвали “кабак”. Цю назву згодом замінили на “питний будинок”. У багатьох таких будинках, окрім міцних напоїв, подавалися закуски, гарячі страви, різні юшки, пироги і чай, а до чаю - варення та різні солодощі. На зміну питним будинкам і шинкам пізніше, у XVIII ст., прийшли трактири, які відігравали провідну роль у забезпеченні населення їжею і напоями як у містах, так і в сільській місцевості. Трактири поділялися на заклади, які пропонували кімнати та харчування, та на заклади, що пропонували лише харчування та напої. Отже, трактирними закладами вважалися: безпосередньо трактири, ресторації, харчевні, буфети при театрах, балаганах, на пароплавах, в клубах, публічних закладах; фруктові лавки.

У XV ст. постоялі двори створювались при “ямах" - поштових станціях, які знаходились одна від одної на відстані кінного переходу. Послуги розміщення та харчування доповнювали послуги перевезення, які надавала "ямська служба".

У XVI - першій половині XVII ст. одним із торговельних центрів Східної Свропи був Київ. Через нього проходили купецькі каравани з Польщі, Кримського ханства, Туреччини, Молдови, Греції, Угорщини, інших країн Західної Європи, що прямували до Московської держави. Українські купці мали право безмитної торгівлі в прикордонних містах Московії. Для них створювалися спеціальні гостинні двори. На чумацьких і торговельних шляхах України здавались в оренду корчми, що не тільки провадили торгівлю алкогольними напоями, а й слугували місцем ночівлі для подорожніх.

У другій половині XVII ст., коли "козацька християнська республіка" знаходилась на острові Чортомлик, на ії території, поблизу порту, височів "Грецький дім" приміщення для іноземних посланців і купців. Запорізька Січ сама провадила жваву торгівлю, а також слугувала транзитним пунктом у торгівлі всіх українських земель і Московської держави з країнами Сходу.

Крім того, Київ став одним із центрів паломництва, що зумовило потребу у місцях харчування для прочан, до яких в Україні ставилися з особливою повагою. Миряни вважали за честь прийняти їх на ночівлю, пригостити, дати харчів на дорогу. Паломники мали захист при церквах і монастирях, де їм відводили спеціальні помешкання, облаштовували гостинні двори.

Постоялі двори вздовж доріг проіснували до середини XIX ст. і припинили своє існування з виникненням і поширенням залізниць.

Найвагоміший внесок у розвиток кулінарії зробили античні народи - стародавні греки та римляни. Уже у III ст. до н. е. у Римі існували кулінарні школи. Як свідчили давньоримські історики, кухарем і лікарем у той час була чи не кожна освічена людина.

Протягом 2500 років людство поступово удосконалювало як свої смаки, так і тонкощі технології приготування їжі. Прикладом може слугувати європейська кухня, стрімкий розквіт якої припадає на епоху середніх віків і більш пізній період. Першими свою кулінарну майстерність продемонстрували італійці. 3 другої половини XIV ст. центр кулінарного мистецтва Європи перемістився з Італії до Франції. Вміння готувати смачну їжу у Франції отримало потужну державну підтримку. Кулінарні рецепти багатьох страв створювались спочатку в домашніх умовах, а потім удосконалювалися кухарями королів, аристократів. 
У 1375 р. головний кухар французького короля Карла V Гійом Тірель написав (в одному примірнику) першу кулінарну книгу. Цей епізод став значущим у розвитку кулінарного мистецтва і означав, що національна кухня досягла такого рівня розвитку, за якого постала потреба ії кодифікувати, узагальнити і сформулювати основні принципи, що дасть можливість розвивати ремесло.

В Італії перша кулінарна книга під назвою “Доброчесні втіхи” з'явилася тільки у 1470 р. Написали ії монахи латинською мовою.

Перша кулінарна книга в Англії була видана 1508 р. Перша кулінарна книга в США з'явилась 1742 р. Це було перевидання англійської книги Елізи Сміт “Повна книга домогосподарки”. У 1798 р. побачила світ кулінарна книга американського автора Амелії Сіммоне “Американська кухня”.

У 1779 р. в Росії була видана перша кулінарна книга "Короткі кулінарні нотатки" Сергія Друковцева. Особливе зацікавлення викликав “Словник кухарський” Василя Левшина, виданий 1795 р., в якому, окрім рецептів французької, німецької, голландської, англійської кухонь, були зібрані 225 рецептів народних української та російської кухонь.

Несприятливою для розвитку українського кулінарного мистецтва була мода на кухарів-французів. Оскільки більшість страв української кухні, на відміну від страв інших кухонь, відзначається складною рецептурою і комбінованими способами приготування, рецептури і способи приготування багатьох страв зазнали змін, через що погіршились їх смакові якості.

До середини XIX ст. в ресторанах подавали відразу всі замовлені страви. У $30-\mathrm{x}$ роках XIX ст. Францію відвідав російський князь Олександр Куракін, який запропонував подавати страви почергово, в порядку їх розташування в меню. В сучасних ресторанах така система $є$ найпопулярнішою.

До XVI ст. відносять відкриття принципово нових закладів, які назвали кав'ярнями. Їх появі сприяло поширення таких екзотичних напоїв, як кава і чай. У країнах Середнього Сходу чоловіки збиралися у кав'ярнях, щоб поспілкуватися, випити кави або чаю, покурити кальян, також грали в шахи, нарди або ж слухали музику і цікавих оповідачів. Перша така кав'ярня відкрилася в Дамаску 1530 р., згодом - у Каїрі, а перша кав'ярня на території Європи з'явилась у Стамбулі 1554 р.

3 середини XVII ст. кава, а з нею і кав'ярні, з'являється в Свропі. Кав'ярні швидко набули популярності спочатку серед торговців, а пізніше - й серед інших верств населення.

Засновником першої віденської кав'ярні був українець Юрій-Франц Кульчицький, учасник оборони Відня. Як винагороду за порятунок міста він отримав усі полишені турками запаси кави. Згодом за прикладом столиці Австрії кав'ярні відкрилися в інших містах Австро-Угорщини: Празі, Будапешті, Львові, Трієсті. Постійними відвідувачами цих закладів стали вчені, філософи, митці. Мистецтво заварювання кави мало певні особливості й вимагало відповідних знань і умінь. У заможніших родинах утвердився звичай тримати служницю-каварку, яка винятково варила цей напій.

У великих містах кількість кав'ярень сягала кількох десятків. Власницею першої кав'ярні в Англії була гречанка Паскуа Розе. В Парижі перша кав'ярня була відкрита у 1672 р. на площі Сен-Жермен. Її власником був вірменин Паскаль. Уже 
1739 р. у Лондоні налічувалась 551 кав'ярня. Відвідувачів однієї кав'ярні, як правило, об'єднували спільні інтереси, здебільшого професійні.

Перша кав'ярня в Україні та Речі Посполитій з'явилася 1672 р. в Кам'янціПодільському. До Львова мода на каву прийшла у XVIII ст. Пити каву було прийнято з молоком і цукром, з “філіжанок”, а подавали ії в “імбрику” (кавнику). Обидва слова турецького походження - від “фільджан” та “ебрек”.

Німецький мандрівник Коль, який у 1841 р. побував у Львові, дивувався великій кількості кав'ярень і цукерень, стверджував, що львівські кав'ярні кращі та елегантніші, ніж у Дрездені чи інших німецьких містах такої ж величини.

Як правило, кав'ярні збирали навколо себе людей якогось одного фаху. Найдавнішою і найулюбленішою кав'ярнею львів'ян була і є “Віденська кав'ярня”. На відміну від інших подібних закладів, тут збиралися представники найрізноманітніших сфер і професій. Любили сюди приходити політики, науковці, юристи, актори тощо. Назва кав'ярні не була випадковою: вона підкреслювала особливий австрійський стиль. У таких закладах на перше місце ставилась атмосфера, адже відвідувачі проводили тут досить багато часу.

Видатний український письменник, критик, перекладач, етнограф, історик, краєзнавець Іван Франко, який сорок із шістдесяти років прожив у Львові, часто заходив до “Віденської” - на каву, щоб почитати газети. I хоч він уникав товариства, всі, хто хотів 3 ним побачитись, знали, що пополудні його можна знайти саме тут. "Ця щоденна полуднева порція газет, - згадував видатний український історик, громадськополітичний діяч Михайло Грушевський, - була необхідним, як хліб, елементом його життя: як фаховий газетяр він прочитував їх у великій кількості, i се стало його другою натурою".

Другою з найдавніших кав'ярень, після “Віденськоі”, була “Центральна”, розташована на площі Галицькій. У кав'ярні була бібліотека з найбільшою кількістю часописів різними мовами. Ї̈̈ відвідували переважно урядовці.

Особливістю вітчизняних кав'ярень було те, що вони мали помпезні назви: “Імперіал”, "Роял”, “Гранд”. Натомість паризькі кав’ярні, які переважно розташовувалися на кінцевій зупинці трамваю чи автобуса, мали скромніші назви: "Під автобусом", “Під трамваєм", “Все йде чудово”, “На хвильку”.

Розквіт кав'ярень припадає на перше десятиліття XX ст. Так, 1906 р. у Львові було 25 кав'ярень, 1911 р. - 46. На зміну віденському типу кав'ярні прийшов варшавський, що характеризувався більшою увагою до інтер'єру.

Росії мода на каву дісталася тільки у XIX ст. Першими ії підхопили літературні салони Петербурга і Москви. Типово російськими закладами харчування були чайні, що виникли в XIX ст. у Тверській губернії. Переважно їх відкривали на робітничих околицях, поблизу ринків і зупинок візників. Чайні, що відігравали роль громадських осередків, де можна було тверезо і цікаво провести час за розмовами і читанням газет, були більше характерні для Москви, а кав'ярнями, в яких було прийнято “істи” каву, славився Петербург, що, радше, пояснюється близькістю до європейської культури.

До XVI ст. відносять і появу ресторанів. У 1553 р. в Парижі було відкрито перший ресторан “Тур д’Аржан”. Сам термін “ресторан” увійшов в обіг значно пізніше, в дру- 
гій половині XVIII ст. Слово restorant походить від французького restauter, що означає "реставрувати, відновлювати". Раніше так називали суп - головну страву цілодобової таверни Буланже, якого вважають “батьком сучасного ресторану”. Він відомий тим, що в 1767 р. виграв у Верховному суді справу проти гільдії постачальників продуктів харчування, яка володіла монополією на м'ясні страви. Буланже першим запропонував клієнтам широкий асортимент страв.

31800 р. почали переймати у своїх сусідів концепцію ресторану англійці. Англійські ресторани вирізнялися вишуканими стравами, високим рівнем обслуговування та внутрішнім оформленням.

У 1571 р. у Франції вперше було розроблено перелік страв до свята при дворі Карла IX. Оскільки це було епізодичне явище, то назви “меню" воно ще не отримало. Справжнє і постійне меню стали розробляти лише через сто років, у 60-х роках XVII ст. на палацовій кухні короля Людовика XIV. Це були картки з цупкого паперу зі списком страв, які подавалися королю. За межі палацових кухонь меню вийшло значно пізніше і стало використовуватися:

- як загальний список страв, які готувалися в ресторані чи кафе;

- перелік страв на певний період часу (від одного дня до одного року).

3 другої половини XIX ст. меню стало означати перелік закусок, страв для конкретних сніданків, обідів або вечерь на будь-яких підприємствах харчування. Вони змінювалися через день, тиждень, місяць або рік. Отже, з другої половини XIX ст. стало використовуватися меню “а ля карт" (a la carte) і клієнти отримали можливість обирати із запропонованого списку будь-яку страву на свій смак.

На межі XVIII-XIX ст. кулінарне мистецтво та організація ресторанної справи у Франції сягнули високого рівня розвитку. Визнаними майстрами кулінарної справи того часу були Антонін Карем, Урбан Дюбуа, Еміль Бернар, Жорж Агюст Ескофьє.

У виданій 1830 р. п'ятитомній монографії “Кулінарне мистецтво XIX століття" Антонін Карем узагальнив досвід французьких кухарів і кулінарів того часу. Він створив Кулінарну академію, займався удосконаленням техніки обслуговування відвідувачів, розробив правила організації буфетів як методу обслуговування. Карем уклав також власну класифікацію соусів, приготування яких і сьогодні вважається мистецтвом.

Метри французької кухні Урбан Дюбуа та Еміль Бернар удосконалювали свою діяльність при російському царському дворі. Саме вони запровадили техніку прискореного сервірування, завдяки якій страви не встигали охолонути перш ніж їх почнуть їсти. Таке сервірування називалось “обслуговуванням по-російськи”. I Дюбуа, і Бернар запропонували різні методи спрощення процесу обслуговування відвідувачів. Своїми кулінарними рецептами вони поділилися в книгах "Класичні страви", "Вишукані страви”, “Страви народів світу”.

Справжню революцію в організації ресторанної справи здійснив Жорж Агюст Ескофьє (1847-1935). 3 його іменем пов'язане відкриття ресторанів у готелях “Савой”, “Картон” у Лондоні, “Гранд-готель” у Римі, “Рітц” у Парижі, “Іутц Картон” у Нью-Йорку. Ескофьє розробив концепцію ресторанного обслуговування на палубах кораблів, яка передбачала добір і навчання персоналу, і впровадив іiі на теплоходах “Америка" та “Імператор” компанії “Глобал Американ Лайн”. При організації вироб- 
ничих процесів на кухні він застосував наукові принципи: чітко визначив структуру кухонної бригади, функції, ієрархію та службові стосунки. Весь кухонний персонал, від шеф-кухаря до учня, повинен був виконувати роботу згідно з переліком посадових обов'язків, що були чітко сформульовані. У виданій ним “Книзі меню” кожне меню супроводжується таблицею розподілу щоденних обов'язків.

Жорж Агюст Ескофьє сформулював лозунг, актуальний і для сучасної ресторанної справи: “Задовільнити клієнта або його втратити, третього не існує”.

У XIX ст. знову стали відкриватися школи кулінарного мистецтва. Перша 3 них - "Національна тренувальна школа для кухарів", - з'явилася в Англії попри те, що, як відомо, британці не дуже прискіпливо ставляться до вибору їжі. Відкриття школи, ймовірно, було зумовлене економічними причинами: розширенням мережі маленьких кафе і ресторанчиків. Кулінарна школа, відкрита в Парижі 1891 р., мала два відділення: жіноче і чоловіче. Жінок безкоштовно навчали, як провадити домашне господарство. Для чоловіків навчання було платним - вони опановували секрети професійної кулінарії. Їм викладали також історію кухарського мистецтва, ботаніку, ліплення, малювання.

Найдорожчим рестораном Києва наприкінці XIX ст. був ресторан при готелі “Метрополь”, який належав купцеві Дьякову. Престижними вважались ресторани при готелях “Бель-Вю”, “Европейская”, “Гранд-Отель”, “Континенталь”. Користувались популярністю, але не були надто дорогими ресторани при готелях “Орион”, “Древняя Русь” і “Марсель”. Добрий обід тут коштував 30-40 коп.

Порція кави в кав'ярнях на Хрещатику коштувала 20 коп., у фірмових кав'ярнях "Варшавская" на Лютеранській і "Швейцарская" на Прорізній — 25 коп.

3 80-х років XIX ст. одним з кращих ресторанів Львова був “Атлас", першим власником якого був М.Атласс - відомий виробник горілки. Сюди приходили відомі в місті люди, тут відбувались концерти, літературні вечори, виставки картин.

Дещо пізніше ніж у Європі заклади харчування з'явились у США. Перші постоялі двори тут виникли лише 1607 р. Одна з перших таверн була відкрита в Бостоні 1634 p. В 1642 р. в Нью-Йорку, який тоді називався Новим Амстердамом, таверну відкрили голландські переселенці. Відтоді таверни стали центрами життя громади. Вони процвітали не тільки в містах, а і вздовж великих доріг, зокрема, на перехрестях.

Європейські переселенці привезли з собою досвід організації постоялих дворів і таверн, який накопичували століттями. Проте перші американські заклади харчування дещо відрізнялися від європейських. Так, при розміщенні людей тут не було дискримінації за класовою приналежністю чи майновим станом. На відміну від європейських підприємств, які багато в чому виконували соціальну функцію, американські таверни від самого початку свого існування мали комерційну спрямованість.

Вважають, що першим рестораном у США був відкритий 1831 р. в Нью-Йорку ресторан “Дельмоніко”. Згодом ця назва стала синонімом вишуканої їжі та бездоганного обслуговування.

На розвиток ресторанної справи у США того часу помітно вплинули французькі кулінарні традиції. До 1852 р. кожен першокласний американський готель мав свого французького шеф-кухаря. Меню також традиційно друкувалось французькою мовою, що дратувало англомовних відвідувачів. Завдяки Джону Дельмоніко, одному з власни- 
ків ресторанів “Дельмоніко”, вперше було запропоноване двомовне меню, в якому назви страв французькою та англійською мовами розташовувались одна навпроти іншої. Згодом ця традиція поширилась у всьому світі.

Отже, виявлені тенденції розвитку ресторанного господарства як у світі загалом, так і в Україні зокрема, особливості і здобутки еволюції закладів ресторанного господарства можуть бути використані для обгрунтування й удосконалення можливих змін в розвитку ресторанної справи в майбутньому.

\section{СПИСОК ВИКОРИСТАНОЇ ЛІТЕРАТУРИ}

1. Агафонова Л. Г., Агафонова О. С. Туризм, готельний та ресторанний бізнес: ціноутворення, конкуренція, державне регулювання: Навчальний посібник. - К.: Знання України, 2002. - 352 с.

2. Архіпов B.B. Організація ресторанного господарства: Навчальний посібник. - К.: Центр учбової літератури, 2007. - 280 с.

3. Дурович А.П. Маркетинг гостиниц и ресторанов. - М.: Новое знание, 2006.

4. Кабушкин Н. И., Бондаренко Г. А. Менеджмент гостиниц и ресторанов: Учебник. Минск: Новое знание, 2003. - 368 с.

5. Нечаюк Л.І., Нечаюк Н.О. Готельно-ресторанний бізнес: менеджмент. - Навч. пос. К.: Центр учбової літератури, 2009. - 344 с.

6. Організація обслуговування у закладах ресторанного господарства: Підручник / За ред. Н.О. П'ятницької - 2-ге вид. перероб. та доп. - К.: Центр учбової літератури, 2011. $-584 \mathrm{c}$.

7. Уокер Дж.Р. Введение в гостеприимство: Учебник; Пер. с англ. - 2-е изд. - М.: ЮНИТИ-ДАНА, 2002. - 607 с.

Стаття: надійшла до редколегї 29.05.2012 прийнята до друку 08.06.2012 


\title{
RETROSPECTIVE ANALYSIS OF RESTAURANT INDUSTRY ESTABLISHMENTS
}

\author{
O. Hatalyak, N. Hanych \\ Ivan Franko National University of Lviv, \\ vul. Universytetska 1,Lviv 79000, Ukraine, tel. (032) 239-41-32
}

Development of restaurant industry establishments is elucidated in retrospective, historical periods of restaurant industry development is analyzed.

Key words: restaurant industry, taverns, caravanserais, coffee houses, restaurants

\section{РЕТРОСПЕКТИВНЫЙ АНАЛИЗ РАЗВИТИЯ ЗАВЕДЕНИЯХ РЕСТОРАННОГО ХОЗЯЙСТВА}

\section{О. Гаталяк, Н. Ганич}

Львовский национальный университет имени Ивана Франко ул. Университетская, 1, г. Львов 79000 Украина

Освещены развитие учреждений ресторанного хозяйства в ретроспетиви, проанализированы исторические периоды развития сферы ресторанного хозяйства.

Ключевые слова: ресторанное хозяйство, таверны, караван-сараи, кафе, рестораны. 